\title{
Predicting the Financial Behavior of the Religious Organization Board in Indonesia
}

\author{
Djamila ABBAS ${ }^{1}$, Muhammad ALI ${ }^{2}$, Mursalim NOHONG ${ }^{3}$, Muhammad SOBARSYAH ${ }^{4}$ \\ Received: September 10, 2020 Revised: November 02, 2020 Accepted: November 16, 2020
}

\begin{abstract}
The religious organization members have a unique take on the spiritual factors related to their daily life. The present study contributed to the lack of discussion investigating this particular pool of data's financial behavior. This article regressed several predictors of economic behavior, i.e., the locus of control, financial attitude, income, and religiosity, with 460 respondents. The results of the research are as follows: Financial attitude partially influences the financial behavior of Muhammadiyah committee members. Income partially influences the financial behavior of Muhammadiyah committee members. This research indicates that income is one of the factors that plays an essential role in determining the merits of improvement of the financial behavior of Muhammadiyah committee members. The higher the level of income received by Muhammadiyah members, the higher the desire to spend the money. Religiosity partially influences the financial behavior of the religious board of Muhammadiyah members in Indonesia. The higher the religiosity of Muhammadiyah committee members will encourage better financial management. Religiosity indicates how often individuals or Muhammadiyah members practice the religious sharia that they embrace. The findings of this study reveal that locus of control, financial attitude, income, and religiosity are the strong predictors of the board of the religious organization's financial behavior in Indonesia.
\end{abstract}

Keywords: Locus of Control, Financial Attitude, Income, Religiosity, Financial Behavior, Religious Organization

JEL Classification Code: G41, G51, H31, H32

\section{Introduction}

The majority of people still have inadequate knowledge about money management and how it has caused many

${ }^{1}$ First Author and Corresponding Author. Lecturer, Department of Management, Faculty of Economics, Universitas Muhammadiyah Maluku Utara, Indonesia [Postal Address: Kampus Universitas Hasanuddin KM. 10 Perintis Kemerdekaan, Tamalanrea Kota Makassar, South Sulawesi, 90241, Indonesia]

Email: djamilaabbas.ummu@gmail.com

${ }^{2}$ Professor, Department of Management, Faculty of Economics and

Business, Universitas Hasanuddin, Indonesia.

Email: muhd.alilakatu@fe.unhas.ac.id

${ }^{3}$ Associate Professor, Department of Management, Faculty of Economics and Business, Universitas Hasanuddin, Indonesia. Email: mursalimnohong@fe.unhas.ac.id

${ }^{4}$ Associate Professor, Department of Management, Faculty of Economics and Business, Universitas Hasanuddin, Indonesia. Email: msobarsyah@gmail.com

(c) Copyright: The Author(s)

This is an Open Access article distributed under the terms of the Creative Commons Attribution Non-Commercial License (https://creativecommons.org/licenses/by-nc/4.0/) which permits unrestricted non-commercial use, distribution, and reproduction in any medium, provided the original work is properly cited. people to experience financial problems, either in form of declining economic conditions and financial issues due to inflation or increasing development of consumerism in the society (Enrico et al., 2013; Sitepu, 2017). Indonesian financial behavior tends to be consumptive, leading to various irresponsible financial behaviors such as lack of saving, investing, emergency fund planning, and future budgeting (Kholid et al., 2020). This phenomenon is evident from the results of the 2013 Otoritas Jasa Keuangan, Indonesia (OJK) study, which found that public financial literacy is still at the middle level, which is $75.69 \%$. Only $21.84 \%$ know a variety of financial products and services (Yucha et al., 2020). This empirical phenomenon becomes one of this research foundations to investigate Indonesia's religious community further.

Even in Southeast Asian countries, Indonesia ranks lowest in terms of gross national savings/GDP, as much as $30.87 \%$, compared to $46.73 \%$ in Singapore (IMF). This condition may result from the harsh life of people, the impulsive consumption, or lack of financial knowledge (Lusardi et al., 2010a, 2010b; van Rooij et al., 2012). People who have a substantial income may not be able to manage 
their financial spending properly, and this happens because of irresponsible economic behavior (Mokhtar et al., 2020; Sudarsono et al., 2020), which also tends to make individuals think short-term and is identical with impulsive shopping practices (Bulutoding et al., 2020; Haerani et al., 2019). Thus, individuals with substantial incomes often experience financial problems (Parmitasari, Alwi, \& Sunarti, 2018; Meghir \& Pistaferri, 2011). It is because lifestyle changes as the luxury lifestyle pushes further needs (Lusardi et al., 2010b).

This research contributes to the absence of discussion on the financial behavior of the administrators of religious organizations in Indonesia; moreover, Indonesia is a country with the largest Muslim population in the world (Suhartini \& Anisa, 2017). This particular investigation probes the financial behavior of the Muhammadiyah committee, as they stand as the second-largest religious organization in Indonesia, with 50 million active members. This organization members proudly claim their moderate view in daily life and actively campaign their education activities. Furthermore, this research investigates the locus of control, financial attitude, income, and religiosity as the predictors of the financial behavior of the respondents. The aim is to expand the knowledge of the financial behavior of religious members as well as to find out as to which independent variables contribute the most.

\section{Literature Review Hypothesis Development}

\subsection{Financial Behavior}

There are several definitions of financial behavior, including a study that studies how psychological phenomena affect financial behavior by stating practitioners' level of behavior (Shefrin \& Statman, 2000). There is another definition as anything relevant regarding personal money management (Xiao, 2008). Nofsinger defines financial behavior as studying how humans behave in financial matters, specifically how the decision-making process takes place related to financial decisions (Nofsinger, 2001; Nofsinger \& Varma, 2014; Ricciardi, 2008). From the various definitions above, this study examines financial behavior in terms of how committee members of Muhammadiyah religious organization make multiple financial decisions.

\subsection{Locus of Control}

Rotter first coined the concept of locus of control as a person's perspective on an event, whether he feels able or not able to control the behavior that occurs to him (Rotter, 1966). There are various ways to measure locus of control, including the dimensional measurement at work. It significantly affects job satisfaction, the intention of quitting, perceived influence, role of stress, perception of supervisor style (Spector, 1988), or health management (Wallston et al., 1978). Next are the following developments in various sectors of the financial world (Cobb-Clark et al., 2016). Locus of control is divided into internal and external triggers, with subjective belief internally pushes the agenda, and outside factors, driving the external consideration in making a decision (Caliendo et al., 2015). In this research, locus of control is thought to be a predictor of Muhammadiyah committee members financial behavior. Several previous research types significantly supported the relationship between these two variables (Britt et al., 2013; Ida \& Dwinta, 2010; Perry \& Morris, 2005). As the realm of influences predicts financial behavior, this study hypothesizes:

H1: Locus of Control improves the financial behavior of Muhammadiyah committee members.

\subsection{Financial Attitude}

Attitude is an evaluative statement, both pleasant and unpleasant towards objects, individuals, and events (Robbins \& Judge, 2009). Attitude towards money is preliminary the creation of behavior related to money (Falahati, 2011). Another definition explains the financial attitude as a state of mind, opinion, and the opinion of a person related to financial aspects (Ameliawati \& Setiyani, 2018). Previous researches support the relationship between financial attitude and financial behavior (Ameliawati \& Setiyani, 2018; Falahati, 2011; Lai, 2010; Yap et al., 2018); it is formulated:

H2: Financial attitude has a relationship with the financial behavior of Muhammadiyah committee members.

\subsection{Income}

Income can be interpreted as a result which is obtained from someone's hard work at his job and is assessed with a certain level or value. In meeting needs, everyone, in general, will rely on the source of spending from the income earned from work (Cobb-Clark et al., 2016; Delafrooz \& Paim, 2011). A person's income is an essential source of information and stimulus in carrying out various activities, especially the money management of individuals. As income changes how individuals shape their financial behavior (Delafrooz \& Paim, 2011; Ida \& Dwinta, 2010; Perry \& Morris, 2005), the following hypothesis is formulated:

H3: Changes in the income of Muhammadiyah committee members will have an impact on their financial behavior.

\subsection{Religiosity}

Religiosity is an attitude or awareness that arises based on one's belief or belief in religion (Hess, 2012). 
Religious attitude is a condition that exists in a person, which encourages him to behave according to the level of adherence to religion, including spending decisions (Ashraf Ali, 2016). As committee board members of a religious organization, they certainly have a relatively conservative view of religious teachings. Because religious factors are necessary prerequisites in the daily activities of board members of a religious organization, their financial behavior is also formed from that aspect ( Vu, 2020). Several previous pieces of research support this opinion (Ali, 2016; Hess, 2012; Hilary \& Hui, 2009; Kashyap \& Iyer, 2009; Renneboog \& Spaenjers, 2012), then it is expected that:

H4: Religiosity increases the positive financial behavior of the religious members of Muhammadiyah.

\section{Research Methods}

This research is quantitative in nature with a causality associative approach. This approach tries to examine the causality relationship (cause and effect) between two or more variables. In this research, there are five investigated variables: locus of control, financial attitude, income, and religiosity, predicting the independent variable of financial behavior. The specific data source is primary responses from the committee members of Muhammadiyah, as the secondlargest religious organization in Indonesia, amounting to 50 million followers.

We selected the sample from the committee members because the higher ranks have a better knowledge of the specific issues, especially religious experience, compared to the regular participants. This study consists of data from 460 people and it employs a random sampling technique as a convenient means. This sample size satisfies the essential requirement of survey responses (Hair et al., 2010) or even the g-power of (Cohen, 1977) by filling the online survey (google form), sent to each committee's WhatsApp group from multiple regions in Indonesia. This research uses inferential statistics to examine the relationship between research variables with a multiple regression method. Regression analysis is used to process the latest data after previously ensuring the suitability of the data under the essential normality, multicollinearity, autocorrelation, and heteroscedasticity through using the SPSS version 22.

\section{Results and Discussion}

\subsection{Results of Analysis}

This study conducts a thorough assessment of the validity, reliability, and classical assumptions of the investigated data. The reports are in Table 1 and states the developed statements used in this study. It reveals six items for the locus of control, four articles for financial attitude, two ideas for income, five reports for religiosity, and four financial behavior items. This evaluation observed the items' validity and reliability by assessing the associated loadings, showing that all instruments are valid as tools or statements to measure the researched variable. The conservative cut-off value is 0.70 (Hair et al., 2010); however, the more moderate view is considered the loading to be lower than 0.50 (Hair, Hult, Ringle, \& Sarstedt, 2014). Further consent over the deletion of the items below 0.5 has to consider the Cronbach's alpha and AVE or not to delete them if the number of items is lesser than 3 (Hair, Hult, Ringle, \& Sarstedt, 2014; Lowry \& Gaskin, 2014). From 21 statements, only 4 of them come with a loading lower than 0.7 , with the most downloading was Loc 2 of 0.577 . The revelation suggests a pretty good cut-off value of the result.

This study also provided several tests like Cronbach's alpha, the collinearity, heteroscedasticity, and normality tests. The results reveal satisfactory findings with the convergent validity of the Cronbach's alpha above 0.7 for each construct.

The VIF score of all constructs is between 1-3, revealing good collinearity. It also proves the nonexistence of common method bias, as the VIF which is lower than 3 indicates it (Podsakoff et al., 2003). This study finds the absence of heteroscedasticity with a significance score above 0.05 . Lastly, the data is normally distributed, as revealed from the Kolmogorov-Smirnov score lesser than 1. All the validity, reliability and the classical assumptions provide support to the employed data in this study. The next is to regress the variables in a nomological validity. The summary of the inferential statistics are as in Table 2.

Based on the table, $\mathrm{R}$ square's value is 0.564 or $56.4 \%$, which means the variable of financial behavior of the board of religious organization of Muhammadiyah can be explained from the four variables of locus of control, financial attitude, income, and religiosity. In comparison, other causes explain the rest (100\% - 56.4\% $=43.6 \%$ ) outside the model. For the F test, the f-count value of 17.916 is found. We can see that the F-count value $>$ F-table value $(17.816>4.01)$ with a probability of 0,000 (significant level of 0,000 ). Therefore, based on the way of decision making of the simultaneous test in regression analysis, it can be concluded that the locus of control (X1), financial attitude (X2), income (X3), and Religiosity (X4) variables if tested together or simultaneously have a significant effect on the variable of financial behavior of the Muhammadiyah committee members (Y). 
Table 1: Summary of Validity and Reliability Test

\begin{tabular}{|c|c|c|c|c|c|c|}
\hline Construct & Item & Statements & Loading & $\alpha$ & VIF & Heteros. \\
\hline \multirow{6}{*}{$\begin{array}{l}\text { Locus of } \\
\text { control }\end{array}$} & Loc1 & Ability to solve personal problems & 0.773 & \multirow{6}{*}{0.813} & \multirow{6}{*}{1,407} & \multirow{6}{*}{.483} \\
\hline & Loc2 & Self-control & 0.577 & & & \\
\hline & Loc3 & Believe in one's self & 0.794 & & & \\
\hline & Loc4 & More easily influenced by the environment & 0.735 & & & \\
\hline & Loc5 & Powerless in dealing with life problems & 0.748 & & & \\
\hline & Loc6 & Having initiative & 0.680 & & & \\
\hline \multirow{4}{*}{$\begin{array}{l}\text { Financial } \\
\text { attitude }\end{array}$} & Fati1 & Saving routinely and regularly & 0.582 & \multirow{4}{*}{0.784} & \multirow{4}{*}{1,776} & \multirow{4}{*}{.340} \\
\hline & Fati2 & Writing plans (budget) & 0.767 & & & \\
\hline & Fati3 & Being economical for money & 0.869 & & & \\
\hline & Fati4 & Taking responsibility for one's self & 0.769 & & & \\
\hline \multirow[t]{2}{*}{ Income } & Inc1 & I have a sufficient source of income from my wage & 0.871 & \multirow[t]{2}{*}{0.784} & \multirow[t]{2}{*}{2,037} & \multirow{2}{*}{.751} \\
\hline & Inc2 & My salary is my primary source of income & 0.922 & & & \\
\hline \multirow{5}{*}{ Religiosity } & Rel1 & I completely understand the five pillars of faith in Islam & 0.841 & \multirow{5}{*}{0.869} & \multirow{5}{*}{1,257} & \multirow{5}{*}{.183} \\
\hline & Rel2 & I understand entirely other fundamental principles in Islam & 0.747 & & & \\
\hline & Rel3 & I strive to meet the regulation of Islam, despite being hard & 0.736 & & & \\
\hline & Rel4 & I strive to meet the regulation of Islam, despite being costly & 0.884 & & & \\
\hline & Rel5 & The purpose of my life is to meet the religious needs & 0.862 & & & \\
\hline \multirow{4}{*}{$\begin{array}{l}\text { Financial } \\
\text { behavior }\end{array}$} & Fib1 & Paying bills on time (e.g., electricity, postpaid credit, etc.) & 0.582 & \multirow{4}{*}{0.750} & \multirow{4}{*}{ - } & \multirow{4}{*}{-} \\
\hline & Fib2 & Noting expenses (daily, monthly, yearly) & 0.767 & & & \\
\hline & Fib3 & Providing unexpected fund (emergency fund) & 0.869 & & & \\
\hline & Fib4 & $\begin{array}{l}\text { Comparing prices in markets before deciding to make a } \\
\text { purchase }\end{array}$ & 0.769 & & & \\
\hline & \multicolumn{2}{|c|}{ Kolmogorov-Smirnov's Z } & \multicolumn{4}{|c|}{.750} \\
\hline
\end{tabular}

Table 2: Summary of the Regression Analysis Results

\begin{tabular}{|c|c|c|c|c|c|}
\hline Variable & $\mathbf{R}^{2}$ & F-value & t-value & p-value & Hypothesis \\
\hline Locus of control & \multirow{4}{*}{0.564} & \multirow{4}{*}{17.916} & 2.060 & 0.044 & Accepted \\
\hline Financial attitude & & & 2.019 & 0.048 & Accepted \\
\hline Income & & & 2.225 & 0.030 & Accepted \\
\hline Religiosity & & & 2.401 & 0.020 & Accepted \\
\hline
\end{tabular}


The SPSS output above shows that the t count value of variable $\mathrm{X} 1$ is higher than the t table $(2.060>1.67252)$ with a significance level below 0.05 , which is 0.044 . The t count of variable X2 is greater than the value of t table (2.019 $>1.67252$ ) with a significance level below 0.05 , which is 0.048 , $t$ count of variable $\mathrm{X} 3$ is greater than the value of $\mathrm{t}$ table $(2.225>1.67252)$ with a significance level below 0.05 , which is 0.030 , and t count of variable $\mathrm{X} 4$ is greater than the value of t table $(2.401>1.67252)$ with a significance level below 0.05 which is 0.020 . These results as a whole show a significant influence on each partial relationship of each variable. The discussion will be continued below. Based on the regression test results above, the following equation is obtained:

$$
\begin{aligned}
\mathrm{Y} & =4.753+0.110 \times 1+0.253 \times 2+0.387 \\
& \times 3+0.140 \times 4
\end{aligned}
$$

Equation 1 above shows the value of the equation constant of 4.753. This figure shows that if X1 (Locus of control), X2 (Financial Attitude), X3 (Income), and X4 (Religiosity) is constant or $X=0$, the magnitude of financial behavior is 4.753. Coefficient X1 (Locus of control) shows a coefficient value of $(0.110)$. It means that if there is an increase in the locus of control factor by $1 \%$ of the Muhammadiyah committee members, the locus of control will also increase by a multiplier variable of 0.110 with the assumption that the other independent variables are considered constant. For component X2 (Financial Attitude) shows a coefficient of $(0.235)$. It means that if there is an increase in the financial attitude factor by $1 \%$ of them, then the financial attitude will also increase by a multiplier variable of 0.235 , assuming the other independent variables are considered constant.

The variable X3 (Income) shows a coefficient value of $(0.387)$. It means that if there is an increase in income factor by $1 \%$ of the religious committee members of Muhammadiyah, income will also increase by the multiplier variable 0.387 , assuming that the other independent variables are considered constant. For variable X4 (Religiosity) shows a coefficient value of (0.140). It means that if there is an increase in the religiosity factor by $1 \%$ of Muhammadiyah committee members, religiosity will also increase by a multiplier variable 0.140 with the assumption that the other independent variables are considered constant.

\subsection{Discussion}

The results indicate that locus of control, financial attitude, income, and religiosity play essential roles in determining whether the financial behavior of Muhammadiyah committee members is excellent or poor. The higher the locus of control, financial attitude, income, and religiosity of Muhammadiyah members, the better are the financial behavior of religious committee members. On the contrary, if the locus of control, financial attitude, income, and religiosity is low, then Muhammadiyah committee members' financial behavior will also experience a decrease.

This research is supported by the statement of(Perry \& Morris, 2005) suggesting that three factors influence financial behavior: first, the individual's self-perception of whatever happens in his life. This concept is sometimes called the locus of control. The second is someone's income, and the third is his knowledge. The religiosity factor also influences humans' financial behavior when making various financial decisions (Hess, 2012). The locus of control (X1) partially affects Muhammadiyah's committee members (Y). There is very little research on the relationship between the two constructs. One of them found that students who had a strong external locus of control had more bad financial behavior than those who were strong internally (Britt et al., 2013). A study with data from Indonesia also confirmed this relationship (Ida \& Dwinta, 2010). This locus of control factor also has a good impact on the project team's financial performance, if internal factors dominate, rather than external (Boone et al., 2005). Internal factors are proven to be fairly and positively enhancing individual saving habits (Cobb-Clark et al., 2016). This whole study supported the partial relationship of each variable.

Financial attitude (X2) partially influences the financial behavior of Muhammadiyah committee members (Y). The financial perspective is very much needed by every individual every day and in all aspects of human life and there is no exception to this rule about the financial aspects of religious members of Muhammadiyah. The financial attitude of someone helps these individuals determine their attitude and behavior in financial matters, which are in terms of financial management (Amar et al., 2019), personal financial budgeting, or how individual decisions regarding the form of investment is taken.

The financial attitude regarding money, according to Sohn, is to view money as power freedom, the reward for efforts, or evil. In other words, the attitude towards money is how one has a view of money, which is money as a source of strength and freedom, achievement, or a source of crime (Sohn et al., 2012). Therefore, financial attitude is critical in determining a person's financial management behavior (Yap et al., 2018). A study on 32 different tribes found that intelligence in managing personal monetary factors will positively impact individual behavior to shape financial behavior; however, the attitude that is too fond of money will encourage dishonesty (Tang et al., 2018). These various studies provided essential clues about the relationship between variables.

Income (X3) partially influences the financial behavior of Muhammadiyah committee members (Y). This research indicates that income is one of the factors that plays an essential role in determining the merits of improvement of the 
financial behavior of Muhammadiyah committee members. The higher the level of income received by Muhammadiyah members is, the higher the desire to spend the money. The willingness of Muhammadiyah members who want to spend their received income without financial control can cause failure in managing finances. Income is one of the relevant demographic factors in explaining an individual's financial behavior, in addition to financial knowledge and marital status (Delafrooz \& Paim, 2011). The findings proved the role of income in shaping individual behavior (Perry \& Morris, 2005).

Religiosity (X4) partially influences the financial behavior of the religious board of Muhammadiyah (Y) in Indonesia. If the religiosity of Muhammadiyah committee members is higher, it will encourage better financial management. On the contrary, if religiosity is low, financial management will get worse as well. Religiosity indicates how often individuals or Muhammadiyah members practice the religious sharia that they embrace. The Muhammadiyah members who increasingly carry out their religion's commands become more spiritual, and vice versa. These individuals stay away from the restrictions taught by Islam; they will be more religious. This finding supports studies that suggest the role of religious factors in shaping consumer behavior (Ashraf Ali, 2016).

The impact of religious factors is even felt in case of countries like the United States, which is classified as more religious, show a lower risk of exposure, and show how the role of religion in holding the pace of action of their religious members to look for risks (Hilary \& Hui, 2009). These factors differentiate various individual investment decisions (Kashyap \& Iyer, 2009). At the household level, the hypothesis of religion's role in its members' financial attitude is also proved to be significant (Renneboog \& Spaenjers, 2012). This whole study supported the role of religion in shaping the financial behavior of its religious members (Hess, 2012). Based on the analysis above, this study findings can be justified, both empirically and theoretically.

\section{Conclusions}

This study reveals that locus of control, financial attitude, income, and religiosity are the strong predictors of the board of the religious organization financial behavior in Indonesia. Interestingly, religiosity is the most dominant component affecting financial behavior, as revealed from the test's t-value. This article also contributes to the lack of exploratory studies on the locus of control toward financial behavior, which finds a positive relationship between locus of control and financial behavior. Other variables are also found to be increasing the predicted variable. This study undoubtedly still has weaknesses. SPSS would limit each indicator's ability to explain the subject construct and further research with a structural model allowing the study's router model's capture. Data analysis from several religious organizations will also benefit explaining the topic as this paper investigates only one organization, despite the fact that it is the second largest. We leave these issues to look up to in the future inquiries.

\section{References}

Amar, M. Y., Syariati, A., \& Rahim, F. R. (2019). Enhancing hotel industry performance through service based resources and strategic enterpreneurship (Case Study At Hotel Industries In Indonesia). Academy of Entrepreneurship Journal, 25(3), 1-10.

Ameliawati, M., \& Setiyani, R. (2018). The influence of financial attitude, financial socialization, and financial experience to financial management behavior with financial literacy as the mediation variable. KnE Social Sciences. https://doi. org/10.18502/kss.v3i10.3174

Ali, A. K. (2016). Impact of religiosity on buying behavior of financial products: a literature review. International Journal of Finance and Banking Research. https://doi.org/10.11648/j. ijfbr.20160201.14

Boone, C., Van Olffen, W., \& Van Witteloostuijn, A. (2005). Team locus-of-control composition, leadership structure, information acquisition, and financial performance: A business simulation study. Academy of Management Journal. https://doi. org/10.5465/AMJ.2005.18803929

Britt, S., Cumbie, J. A., \& Bell, M. M. (2013). The influence of locus of control on student financial behavior. College Student Journal.

Bulutoding, L., Habbe, A. H., Parmitasari, R. D. A., Alwi, Z., \& Abdullah, M. W. (2020). Moslem taxpayers' compliance behavior in Malaysia. International Journal of Advanced Engineering Research and Science. https://doi.org/10.22161/ ijaers. 73.35

Caliendo, M., Cobb-Clark, D. A., \& Uhlendorff, A. (2015). Locus of control and job search strategies. Review of Economics and Statistics. https://doi.org/10.1162/REST_a_00459

Cobb-Clark, D. A., Kassenboehmer, S. C., \& Sinning, M. G. (2016). Locus of control and savings. Journal of Banking and Finance. https://doi.org/10.1016/j.jbankfin.2016.06.013

Cohen, J. (1977). The concepts of power analysis. In Statistical Power Analysis for the Behavioral Sciences. https://doi. org/10.1016/b978-0-12-179060-8.50006-2

Delafrooz, N., \& Paim, L. (2011). Personal saving behavior among malaysian employees: Socio demographic comparison. International Conference on Social and Humanity.

Enrico, A., Aron, R., \& Oktavia, W. (2013). The Factors that influenced consumptive behavior: A survey of university students in Jakarta. SSRN Electronic Journal. https://doi. org/10.2139/ssrn.2357953

Falahati, L. (2011). A comparative study in money attitude among university students: A gendered view. Journal of American Science. 
Haerani, S., Parmitasari, R. D. A., Aponno, E. H., \& Aunalal, Z. I. (2019). Moderating effects of age on personality, driving behavior towards driving outcomes. International Journal of Human Rights in Healthcare. https://doi.org/10.1108/ IJHRH-08-2017-0040

Hair, J. F., Hult, G. T. M., Ringle, C. M., \& Sarstedt, M. (2014). Partial least squares structural equation modeling (PLS-SEM). In Sage Publisher. https://doi.org/10.1108/EBR-10-2013-0128

Hair, J., Black, W., Babin, B., \& Anderson, R. (2010). Multivariate data analysis: A global perspective. Multivariate Data Analysis: A Global Perspective.

Hess, D. (2012). The impact of religiosity on personal financial decisions. 14, 1-13.

Hilary, G., \& Hui, K. W. (2009). Does religion matter in corporate decision making in America? Journal of Financial Economics. https://doi.org/10.1016/j.jfineco.2008.10.001

Ida, \& Dwinta, C. Y. (2010). The influence of locus of control, financial knowledge, income on financial management behavior. Journal of Business and Accounting. (in Indonesian).

Kashyap, R., \& Iyer, E. S. (2009). Not everybody wants to save the world. Journal of Financial Services Marketing. https://doi. org/10.1057/fsm.2009.12

Kholid, M. N., Tumewang, Y. K., \& Salsabilla, S. (2020). Understanding students' choice of becoming certified sharia accountant in Indonesia. Journal of Asian Finance, Economics and Business, 7(10), 219-230. https://doi.org/10.13106/ jafeb.2020.vol7.n10.219

Lai, C. W. (2010). How financial attitudes and practices influence the impulsive buying behavior of college and university students. Social Behavior and Personality. https://doi. org/10.2224/sbp.2010.38.3.373

Lowry, P. B., \& Gaskin, J. (2014). Partial least squares (PLS) structural equation modeling (SEM) for building and testing behavioral causal theory: When to choose it and how to use it. IEEE Transactions on Professional Communication. https:// doi.org/10.1109/TPC.2014.2312452

Lusardi, A., Mitchell, O. S., \& Curto, V. (2010a). Financial literacy among the young: Evidence and implications. National Bureau of Economic Research, 358-380.

Lusardi, A., Mitchell, O. S., \& Curto, V. (2010b). Financial literacy among the young. Journal of Consumer Affairs. https://doi. org/10.1111/j.1745-6606.2010.01173.x

Meghir, C., \& Pistaferri, L. (2011). Earnings, consumption and life cycle choices. In: Handbook of Labor Economics. https://doi. org/10.1016/S0169-7218(11)02407-5

Mokhtar, N., Sabri, M. F., Soke, C., \& Ho, F. (2020). Financial capability and differences in age and ethnicity. Journal of Asian Finance, Economics and Business, 7(10), 1081-1091. https:// doi.org/10.13106/jafeb.2020.vol7.no10.1081

Nofsinger, J. R. (2001). The impact of public information on investors. Journal of Banking and Finance. https://doi. org/10.1016/S0378-4266(00)00133-3
Parmitasari, R. D. A., Alwi, Z., \& Sunarti, S. (2018). The influence of spiritual intelligence and hedonism lifestyle on personal financial management of state higher education students in makassar city. Jurnal Minds: Manajemen Ide Dan Inspirasi. (in Indonesian). https://doi.org/10.24252/minds.v

Podsakoff, P. M., MacKenzie, S. B., Lee, J. Y., \& Podsakoff, N. P. (2003). C5i2.5699

Perry, V. G., \& Morris, M. D. (2005). Who is in control? the role of self-perception, knowledge, and income in explaining consumer financial behavior. Journal of Consumer Affairs. https://doi.org/10.1111/j.1745-6606.2005.00016.x

ommon method biases in behavioral research: a critical review of the literature and recommended remedies. Journal of Applied Psychology. https://doi.org/10.1037/0021-9010.88.5.879

R. Nofsinger, J., \& Varma, A. (2014). Pound wise and penny foolish? OTC stock investor behavior. Review of Behavioral Finance. https://doi.org/10.1108/RBF-12-04-02

Renneboog, L., \& Spaenjers, C. (2012). Religion and Finance. In Socially Responsible Finance and Investing: Financial Institutions, Corporations, Investors, and Activists. https://doi. org/10.1002/9781118524015.ch8

Ricciardi, V. (2008). The Psychology of Risk: The Behavioral Finance Perspective. Handbook of Finance. https://doi. org/10.1002/9780470404324.hof002010

Robbins, S., \& Judge, T. (2009). Organizational Behaviour: Concepts, Controversies, Applications. In Development.

Rotter, J. B. (1966). Generalized expectancies for internal versus external control of reinforcement. Psychological Monographs. https://doi.org/10.1037/h0092976

Shefrin, H., \& Statman, M. (2000). Behavioral portfolio theory. The Journal of Financial and Quantitative Analysis. https://doi. org/10.2307/2676187

Sitepu, N. I. (2017). Islamic consumption behavior in Indonesia. Journal of Darussalam Economic Perspective. (in Indonesian). https://doi.org/10.24815/jped.v2i1.6650

Sohn, S. H., Joo, S. H., Grable, J. E., Lee, S., \& Kim, M. (2012). Adolescents' financial literacy: The role of financial socialization agents, financial experiences, and money attitudes in shaping financial literacy among South Korean youth. Journal of Adolescence. https://doi.org/10.1016/j. adolescence.2012.02.002

Spector, P. E. (1988). Development of the Work Locus of Control Scale. Journal of Occupational Psychology. https://doi. org/10.1111/j.2044-8325.1988.tb00470.x

Sudarsono, H., Nuri, R., \& Nugrohowati, I. (2020). Determinants of the intention to consume halal food, cosmetics and pharmaceutical products. Journal of Asian Finance, Economics and Business, 7(10), 831-841. https://doi.org/10.13106/ jafeb.2020.vol7.no10.831

Suhartini, E., \& Anisa, N. (2017). The influence of emotional intelligence and spiritual intelligence on nurse performance in labuang baji makassar regional hospital. Jurnal Minds: 
Manajemen Ide Dan Inspirasi. (in Indonesian). https://doi. org/10.24252/minds.v4i1.3135

Tang, T. L. P., Sutarso, T., Ansari, M. A., Lim, V. K. G., Teo, T. S. H., Arias-Galicia, F., Garber, I. E., Chiu, R. K. K., CharlesPauvers, B., Luna-Arocas, R., Vlerick, P., Akande, A., Allen, M. W., Al-Zubaidi, A. S., Borg, M. G., Cheng, B. S., Correia, R., Du, L., Garcia de la Torre, C., Adewuyi, M. F. (2018). Monetary intelligence and behavioral economics: the enron effect: Love of money, corporate ethical values, corruption perceptions index (CPI), and dishonesty across 31 geopolitical entities. Journal of Business Ethics, 148(4), 919-937. https:// doi.org/10.1007/s10551-015-2942-4

van Rooij, M. C. J., Lusardi, A., \& Alessie, R. J. M. (2012). Financial literacy, retirement planning and household wealth. Economic Journal. https://doi.org/10.1111/j.14680297.2012.02501.x

$\mathrm{Vu}$, H. M. (2020). Relationship between work-life balance, religiosity and employee engagement: A proposed moderated mediation model. Journal of Asian Finance, Economics and
Business, 7(10), 339-345. https://doi.org/10.13106/jafeb.2020. vol7.n10.339

Wallston, K. A., Wallston, B. S., \& DeVellis, R. (1978). Development of the multidimensional health locus of control (MHLC) scales. Health Education \& Behavior. https://doi. org/10.1177/109019817800600107

Xiao, J. J. (2008). Applying behavior theories to financial behavior. Handbook of Consumer Finance Research. https://doi. org/10.1007/978-0-387-75734-6_5

Yap, R. J. C., Komalasari, F., \& Hadiansah, I. (2018). The effect of financial literacy and attitude on financial management behavior and satisfaction. Bisnis \& Birokrasi Journal. https:// doi.org/10.20476/jbb.v23i3.9175

Yucha, N., Setiawan, S., Muttaqiin, N., Ekasari, R., \& Mauladi, K. F. (2020). Digital payment system analysis of buying decision in Indonesia. Journal of Asian Finance, Economics and Business, 7(10), 323-328. https://doi.org/10.13106/jafeb.2020. vol7.n10.323 